\title{
FENOMENA GERAKAN POPULISME DALAM KEMUNDURAN DEMOKRASI
}

\author{
Muhammad Irfan Hilmy \\ Universitas Brawijaya, Indonesia \\ Email: irfanhilmy37@gmail.com
}

\begin{abstract}
ABSTRAK
Artikel ini membahas mengenai kemunduran demokrasi yang disebabkan oleh berkembangnya gerakan populis di Dunia. Gerakan tersebut berdampak pada perumusan kebijakan yang diskriminatif di berbagai negara dan menciptakan disintegrasi nasional akibat propaganda nativisme yang disuarakan oleh kelompok populis. Analisis dilakukan terhadap kondisi beberapa negara demokrasi, terutama di Wilayah Asia dan Amerika. Penelitian ini menggunakan metode penelitian kualitatif dengan menggunakan studi kepustakaan yang berasal dari buku serta artikel jurnal yang membahas mengenai demokrasi. Artikel ini menyimpulkan bahwa gerakan populisme erat kaitannya dengan kemunduran demokrasi dan disintegrasi suatu bangsa. Selain itu, gerakan populisme memperkuat paham nativisme yang membedakan antara kelompok masyarakat pribumi dengan masyarakat asing. Gerakan ini pun dianggap sebagai gerakan kontra demokrasi yang berdampak pada berjalannya proses demokrasi di suatu negara. Tujuan dari penulisan ini adalah untuk menganalisa penyebab kemunduran dalam demokrasi yang diakibatkan oleh berkembangnya gerakan populisme.
\end{abstract}

Kata Kunci: Demokrasi; Populisme; Nativisme.

\begin{abstract}
This article discusses the degradation of democracy caused by the development of populist movements in the World. The populist movement had an impact on the formulation of discriminatory policies in various countries and created national disintegration due to the propaganda of nativism that be expressed by populist groups. Object of analysis on the conditions of several democracies country, especially in the Asian and American regions. This analysis uses qualitative research methods by using literature studies derived forum books and journal that discuss democracy. This article concludes the populist movement is very related to the degradation of democracy and disintegration of a nation. In addition, the populism movement streghtens the nativism which differentiate between indigenous groups and foreign communities. This movement also considered as a contra-democracy movement that has an impact on the process of democracy in a country. The purpose of this article is to analysis the cause of democracy degradation caused by the development of populist movement.
\end{abstract}

Keyword: Democracy; Populism; Nativism.

\section{PENDAHULUAN}

Seperti permasalahan sosial lainnya, demokrasi pun tumbuh sejalan dengan dinamika bernegara. Sebab itulah demokrasi tumbuh secara berbeda di berbagai negara sepanjang lintasan ruang dan waktu. Dalam catatan satu abad kebelakang, demokrasi selalu hadirmelalui dinamika perkembangan masyarakat dan sistem yang sedang chaos. Misalnya saja masa kegelapan Eropa pada 1930-an, otoritarianisme di Amerika
Latin pada 1970-an (Aart S, 2008), serta tumbangnya rezim otoritarianisme yang setelahnya melahirkan sistem demokrasi di beberapa negara seperti Iran pada 1979, lalu Indonesia pada 1998. Abad lalu menunjukkan bahwa demokrasi menjadi sistem yang diidamkan oleh masyarakat di beberapa negara berkembang untuk menggantikan sistem yang dianggap tidak sesuai. Hal demikian juga disampaikan oleh Schumpeter (1942) yang menilai 
bahwa demokrasi menjadi jembatan antara dua konflik ideologi besar saat itu yaitu kapitalisme dan sosialisme sehingga demokrasi dianggap memiliki nilai ideal untuk menjadi solusi terhadap permasalahan sistem kenegaraan pada abad lalu.

Demokratisasi yang terjadi di berbagai belahan dunia sejak abad lalu, tidak selalu membawa berita baik terhadap perkembangannya. Menurut penelitian yang dilakukan oleh Sarah Repuci (FreedomHouse. org, 2020) bahwa sejak 13 tahun lalu demokrasi di dunia mengalami kemunduran. Ada beberapa aspek yang mengakibatkan kemunduran dalam demokrasi, diantaranya korupsi yang merajalela, gerakan populis yang berkembang, dan penegakan hukum yang lemah. Ketiga faktor tersebut terlihat jelas apabila melihat dinamika hukum dan politik di Indonesia serta negara berkembang lainnya. Ciri yang paling jelas terlihat saat ini akibat dari masifnya ketiga hal tersebut adalah kemunculan oligarki ditengah kehidupan politik negara. Tentu, keberadaan oligarki ditengah demokrasi menjadi ancaman buruk terhadap keberlangsungan demokrasi dalam politik kontemporer saat ini. Seperti yang dideklarasikan oleh Presiden Lincoln (Epstein, 2011) mengenai "Government of the people, by the people, and for the people" yang sangat erat diartikan dalam demokrasi, dewasa ini dengan mudah dapat diraih dengan cara licik oleh para oligarki dalam meraih kekuasaan politik. Sebuah adagium "suara rakyat adalah suara uang" setidaknya menggambarkan salah satu keadaan masa kini mengenai relasi uang terhadap suara pemilih yang pada akhirnya dikenal dengan money politic.

Namun, permasalahan krusial dalam demokrasi tentu tidak hanya mengenai keterkaitan oligarki dengan politik uang. Belakangan waktu ini, beberapa negara besar demokrasi mengadakan pemilihan umum untuk memilih Presiden serta Wakil
Presiden. Seperti, Indonesia (2014 \& 2019), Amerika (2016), dan Brazil (2019) berhasil menarik perhatian masyarakat dunia terhadap pola demokrasi pada ketiga negara tersebut. Dalam pemilihan Presiden yang lalu, para calon di ketiga negara itu secara terang-terangan menggunakan gerakan populisme untuk meraih massa yang besar. Apalagi saat pemilihan Presiden di Indonesia tahun 2014 \& 2019 terlihat jelas sekali bagaimana kedua kubu dalam memainkan isu populisme di Indonesia. Bahkan pasca Pemilu 2014, konflik horisontal sangat rawan terjadi akibat dari residu yang ditinggalkannya.

Para tokoh populis di Dunia seperti Donald Trump, Marine Le Pen, Norbert Hoffer, Nigel Farage, dan Geert Wilders yang sangat terkenal saat ini telah mengubah pola demokrasi dan persaingan partai di negaranya (Ronal $\mathrm{F}$. Inglehart, 2016) akibat penggunaan isu populis. Populisme merupakan kekuatan dengan basis massa yang sangat sulit digoyahkan karena pendekatan yang dilakukan cenderung terhadap permasalahan sosial, misalnya kesenjangan ekonomi dan diskriminasi SARA. Kecenderungan yang terlihat dalam kontestasi politik global dengan menggunakan isu populis terjelma dalam partai politik sayap-kanan yang selalu memperlihatkan kepedulian terhadap isuisu sosial. Kecenderungan lainnya yang digunakan oleh partai politik sayap-kanan adalah dengan menggunakan paham yang membedakan antara pribumi dan non-pribumi (nativisme). Penggunaan narasi seperti itu tentu akan melegitimasi keberadaan partai populis untuk terus mencapai seluruh agenda politiknya. Gagasan nativisme ini terbukti efektif serta turut mempengaruhi hasil dalam kontestasi elektoral seperti yang terjadi di Jerman, yaitu kebangkitan Alternative fur Deutschland (AfD), Front National di Perancis, British National Party di Inggris, dan Bharatiya Janata Party di India (Defby Margiansyah, 2019).

Isu yang dibawa oleh banyak partai 
populis telah mengakibatkan disintegrasi dan ketidakstabilan politik di beberapa negara. Misalnya saja di India yang pada bulan Februari 2020 lalu terjadi kerusuhan besar-besaran (BBC.com, 2019) akibat diloloskannya UU Citizen Amandement Bill (CAB) oleh Perdana Menteri India, Narendra Modi yang berasal dari partai populis besar yaitu BJP. Kerusuhan yang terjadi di India memperkuat isu sektarian karena penyerangan yang dilakukan menyasar masjid dan orang-orang Islam di India. Selain India, di Belanda pun isu populisme digunakan oleh Partij Voor de Vrijheid (PVV) saat pemilihan perdana menteri Belanda dengan kandidatnya yaitu Geert Wilders. PVV mengakibatkan ketidakstabilan politik di Belanda akibat isu anti-Islam yang digunakan oleh mereka. Namun PVV berhasil dikalahkan oleh Volkspartij Voor Vrijheiden Democratie yang merupakan petahana. Keberhasilan mengalahkan PVV menunjukkan bahwa Belanda berhasil meruntuhkan isu populisme yang telah dibangun oleh PVV. Presiden Amerika Serikat terpilih pada 2016 lalu Donald Trump juga sempat membuat situasi politik Amerika Serikat kala itu memanas akibat penggunaan nativisme dan politik anti-Islam untuk menggalang kekuatan suara. Hal tersebut lantas mengakibatkan demonstrasi di beberapa negara bagian. Di Indonesia, pasca dilantiknya Presiden Jokowi pada 2014 silam memantik dan membuka ruang perdebatan baru antara kebangkitan gerakan populis dan menguatnya kaum nasionalis yang mengakibatkan kurang kondusifnya situasi politik beberapa tahun kebelakang. Gerakan populis di Indonesia juga cenderung memakai isu nativisme bahkan saat ini sangat dekat dengan penggunaan isu ideologi untuk menjatuhkan lawan politiknya.

Beberapa negara diatas menjadi contoh buruk dari bangkitnya gerakan populis yang sedang merebak dalam suasana politik kontemporer saat ini. Tentu tidak dapat disimpulkan bahwa gerakan populis selalu membawa dampak buruk bagi iklim politik suatu negara. Disisi lain, gerakan populis merupakan batu uji dari ketahanan demokrasi serta menguji kedewasaan dalam berdemokrasi. Tentu dibutuhkan kecerdasan konstituen dalam menghadapi gelombang gerakan populis di negara-negara Demokrasi. Sama halnya dengan gerakan politik lainnya seperti gerakan konservatif, gerakan populis juga memiliki tujuan politik untuk mendapatkan kekuasaan pada suatu negara.

Awal abad ini memang dapat dikatakan sebagai waktu bagi bangkitnya gerakan populisme global. Dinamika politik pada abad 20 memang menutup kemungkinan adanya kebangkitan gerakan populis karena pada masa itu banyak negara di Dunia yang masih berada dalam satu rezim otoritarianisme. Awal abad21 pun menandai banyaknya negara yang beralih menuju sistem yang demokratis akibat kejenuhan serta tuntutan politik dari masyarakat terhadap rezim yang otoriter. Namun memang tidak sepenuhnya demokrasi memberikan angin segar terhadap kondisi yang kondusif dalam sistem politik. Dinamika yang kompleks mengakibatkan sistem politik pada negara demokrasi sering kali tidak stabil. Kebebasan yang luas dalam demokrasi pun turut mendegradasi moral serta etika dalam dunia politik. Penggunaan segala cara dapat dilakukan termasuk mengerahkan kekuatan populis untuk mencapai kekuasaan semata. Keadaan tersebut menciptakan kerawanan politik akan penggunaan kekerasan serta menguatnya sektarian di berbagai negara demokrasi. Berdasarkan latar belakang diatas maka penulis merumuskan beberapa rumusan masalah yaitu mengenai dinamika gerakan populis global dan pengaruh gerakan populis serta media terhadap kemunduran demokrasi.

Dalam kajian penulisan ini, penulis 
bertujuan untuk memberikan pemahaman terhadap perkembangan gerakan populisme yang mempengaruhi proses kemajuan demokrasi di Dunia. Selain itu, penulis juga bertujuan untuk menyadarkan serta mengedukasi terkait dengan perkembangan gerakan populisme dalam kemunduran demokrasi modern saat ini.

\section{METODE}

Penulis menggunakan metode penelitian kualitatif, yaitu metode yang menggunakan latar belakang alamiah dengan maksud menafsirkan fenomena yang terjadi dan dilakukan dengan jalan melibatkan metode penelitian yang ada (Albi, 2018). Metode penelitian iniberusaha untuk menemukan dan menggambarkan secara naratif suatu fenomena dan dampak yang dihasilkan dari fenomena tersebut.

Penulis menggunakan pendekatan konseptual (conseptual approach), yaitu dengan menganalisis serta menelaah bagaimana konsep demokrasi modern (Johny Ibrahim, 2007), serta menggunakan pendekatan komparasi (comparative approach), yaitu dengan membandingkan praktik gerakan populis di beberapa negara demokrasi. Dalam kajian ini penulis menggunakan teknik pengumpulan data berupa studi kepustakaan yaitu melalui jurnal dan buku ilmiah untuk mendapatkan serta mengetahui informasi terkait demokrasi serta gerakan populisme di Dunia. Dalam artikel ini penulis menggunakan teknik analisis data dengan menarik kesimpulan dan melakukan verifikasi dengan mengkonfigurasi kemungkinan, sebab akibat, dan pola-pola gerakan populisme di Dunia.

\section{HASIL DAN PEMBAHASAN \\ Dinamika Gerakan Populisme Global}

Perkembangan demokrasi modern saat ini ditandai dengan berbagai fenomena sosial politik yang dapat dirasakan dalam dinamika politik belakangan waktu ini.
Revolusi Perancis dan Revolusi Amerika menandai awal kelahiran demokrasi modern yang pada awalnya ditandai dengan dijunjung tingginya asas-asas kemerdekaan individu, kesamaan hak, serta hak pilih yang diberikan kepada semua warga negara (universal suffrage) (Budiardjo, 2008). Namun melihat apa yang terjadi dalam proses demokrasi 13 tahun kebelakang, sekiranya telah terjadi kemunduran demokrasi yang signifikan pada negara-negara demokrasi di seluruh dunia. Indonesia menjadi salah satu negara yang keadaan demokrasinya turut memprihatinkan. Tingkat heterogenitas yang tinggi memang menjadi tantangan besar bagi Indonesia untuk mengemas demokrasi sebaik mungkin agar kestabilan politik dan hukum dapat terjaga dengan baik. Kompleksitas proses demokrasi di Indonesia menurut Economist Intelligence Unit (EIU) mengakibatkan Indonesia berada di peringkat ketiga perihal indeks demokrasi di Asia Tenggara (Noor, 2020). Indonesia masuk kedalam kategori flawed democracy (demokrasi yang cacat) yang dibuktikan dengan tingginya angka money politics, diskriminasi politik, dan kebijakan yang tidak sejalan dengan kepentingan rakyat.

Fenomena politik yang terjadi belakangan waktu ini seiring dengan kemunduran demokrasi global dapat dilihat dari rentetan peristiwa yang terjadi di beberapa negara seperti Amerika Serikat (Trumpisme), Yunani (Syriza), Inggris (Brexit), dan tumbuhnya gerakan untuk membela agama di beberapa negara termasuk Indonesia. Fenomena yang lahir pada keempat negara tersebut merupakan fenomena politik populisme yang merupakan salah satu dampak dari proses demokrasi liberal. Fenomena ini menurut Hawkins (2010) merupakan jejak penting dalam perkembangan demokrasi dunia. Populisme tidak semata-mata ditandai dengan fenomena penguatan satu identitas 
lalu mendiskriminasi identitas lainnya. Melainkan perlu dibedakan dua bentuk gerakan populisme yang dikenal dengan populisme sayap kiri dan populisme sayap kanan. Gerakan populis sayap kiri cenderung untuk menekankan pada permasalahan ekonomi dan gerakan populis sayap kanan cenderung menekankan pada kesenjangan identitas serta penguatan terhadap paham nativisme (Ufen, 2019).

Dalam memahamigerakan populisme setidaknya terdapat tiga pendekatan yang merujuk pada perkembangan gerakan populis di dunia, diantaranya adalah anti establishment, autoritarianism, dan nativisme (Alwi Ritonga, 2020). Ketiga pandangan tersebut menjadi ciri khas gerakan populis untuk menuntaskan citacita populisnya. Perlawanan terhadap elit negara menjadi pokok usaha dari gerakan populis untuk mengumpulkan massa yang memiliki latar belakang yang cenderung sama. Pelfini (dalam Lenger \& Schumpeter, 2006) mengungkapkan bahwa gerakan populis mengumpulkan massa dengan menawarkan pemikiran untuk melawan struktur kekuasaan dengan nilai-nilai dominan yang mereka yakini dengan tujuan terjadinya perubahan atas nama rakyat. Hal selaras juga disampaikan oleh Cas Mudde (2004) yang mengartikan populisme sebagai ideologi yang membangi masyarakat kedalam dua kelompok rakyat melawan kelompok elit yang dianggap korup. Gerakan ini menurut data yang dihimpun oleh Demos menunjukkan cenderung digunakan oleh para aktor politik sebagai jalan pintas untuk mendapatkan kekuasaan (Kariadi, 2009). Ongkos politik yang mahal menjadikan gerakan populis sebagai pilihan murah untuk mendapatkan suara pemilih. Konsep populis pun secara konseptual seringkali samar karena dinamika serta perkembangan zaman. Populisme seringkali bersatu dalam fenomena politik lainnya seperti gerakan nasionalis, ekonomi, dan anti-imigran (Bonikowski, 2016).
Penggunaan pola politik populisme yang didasari pada paham nativisme merupakan pola yang dapat dilihat dari dinamika politik yang terjadi di tiga negara demokrasi besar dunia, yaitu Indonesia, Amerika Serikat, dan India dalam kurun enam tahun kebelakang. Perkembangan gerakan populisme pada ketiga negara tersebutsangatkentarasaatproses pemilihan Presiden dan Perdana Menteri pada tahun 2014 (Indonesia), 2016 (Amerika Serikat), dan India (2019). Di Indonesia isu yang selalu dimainkan oleh kelompok populis berkaitan dengan nativisme adalah isu antara pribumi dengan kelompok asing. Kelompok populis menggunakan narasi bahwa pemerintah tidak berpihak dengan kepentingan rakyat (pribumi) melainkan berpihak pada kelompok lain dalam hal ini adalah golongan asing dan China. Selain itu, strategi politik populisme di Indonesia adalah menggunakan narasi pembelaan terhadap agama yang melahirkan gerakan besar pada tahun 2016 yang dikenal dengan kelompok 212. Fenomena gerakan populis berdasarkan narasi agama merupakan narasi yang biasa terjadi di negara-negara mayoritas Islam di Dunia. Kecenderungan ini dikarenakan mudahnya untuk melakukan mobilisasi terhadap suara mayoritas (kaum agama Islam) untuk memenangkan partai populis. Selain Indonesia, di negara mayoritas Islam lainnya seperti Mesir dan Turki terdapat kecenderungan memakai identitas agama untuk menggalang massa pendukung. Dampak dari gerakan populisme ini menurut Vedi R. Hadiz (2016) mengakibatkan homogenitas di kalangan masyarakat yang tidak mencerminkan toleransi pada masyarakat yang beragam.

Homogenitas struktur masyarakat juga terjadi di India belakangan ini setelah Narendra Modi meloloskan UU Citizenship Amandement Bill (CAB). Modi dengan partainya Bharathiya Jannata Party (BJP) dianggap melakukan diskriminasi terhadap umat Islam India akibatnya banyak terjadi 
kerusuhan di India karena tendensi agama. Selain India, negara maju seperti Inggris pun tak luput dari fenomena populisme yang menguat pada tahun 2016 ketika Inggris memilih keluar dari Uni Eropa atau yang lebih dikenal dengan Brexit. Disparitas kultural antara pribumi dengan imigran di Inggris menguat dalam referendum Brexit membuktikan bahwa referendum pada tahun 2016 juga turut menggunakan isu populisme yang didalangi oleh partai konservatif Inggris yang menginginkan kembalinya citra Inggris sebagai negara superpower di Uni Eropa (Fidya, 2018). Ketakutan terhadap banyaknya imigran yang berdatangan ke Inggris menjadi salah satu isu yang digunakan partai-partai pendukung Brexit, seperti United Kingdom IndependentParty untukmenggalang massa besar. Tentu saja isu ini memperkuat paham nativisme di Inggris yang mengakibatkan diskriminasi sosial antara pribumi dengan kelompok imigran. Selain Inggris, negara maju lainnya yang diguncang populisme adalah Amerika Serikat. Donald Trump dikenal dengan pemimpin populis yang terkenal keras berkampanye menggunakan isu Islamphobia dan rasialisme. Seringkali Trump melemparkan pernyataan rasis kepada orang-orang yang dianggap bukan merupakan orang asli Amerika. Trump (2015) dalam kampanyenya pernah memberikan pernyataan rasis kepada imigran Meksiko yang datang ke Amerika. Ia menyebutkan bahwa orang-orang Meksiko yang datang ke Amerika bukanlah orang yang baik, Trump menyebut mereka para penjahat dan pemerkosa. Seperti strategi populis lainnya, Trump pun juga menawarkan kekuatan untuk melawan elit negara yang dianggap tidak dapat merumuskan kebijakan yang adil (Carlos De La Toree, 2017).

Di Benua Amerika, gerakan populis tidak hanya eksis di Amerika Serikat. Negara-negara di Amerika Latin banyak pula menyimpan cerita mengenai tumbuh dan berkembangnya gerakan populis. Misalnya Rezim Juan Peron yang melakukan pendekatan populis untuk mendapatkan suara rakyat Argentina, lalu gelombang populis yang terjadi di Meksiko yang dikenal dengan gerakan Indignados. Gerakan tersebut pada awalnya hanya mengkritik pemerintah Meksiko akibat peredaran obat bius namun gerakan tersebut bertransformasi menjadi gerakan transnasional yang memprotes terkait kesenjangan ekonomi serta kemiskinan global (Darmawan, 2017). Gerakan populis di Amerika Latin memang banyak berubah menjadi gerakan transnasional yang tidak hanya mengkritik kebijakan negara sendiri, melainkan turut mengomentari isu-isu global terutama terkait dengan kesenjangan serta ketimpangan ekonomi.

Dinamika perkembangan gerakan populis di berbagai negara merupakan efek dari dianutnya demokrasi liberal. Persaingan politikyangketatmengakibatkan parapolitisi harus mencari celah untuk mendapatkan kursi kekuasaan. Ongkos politik yang mahal pun menjadi salah satu faktor dari dianutnya politik populisme untuk mengurangi biaya yang harus dikeluarkan dalam kontestasi pemilihan.

\section{Ancaman Populisme dan Media Terhadap Demokrasi}

Perkembangan akses informasi di seluruh Dunia memudahkan seseorang untuk mendapatkan informasi yang tidak terbatas jumlahnya. Menurut penelitian yang dilakukan oleh Max Roser (Our Worldin Data.org, 2015), kurva penggunaan internet terus naik setiap tahunnya. Akses internet tersebut diikuti dengan penggunaan media sosial yang juga meningkat setiap tahunnya. Penelitian Roser memperlihatkan angka pengguna media sosial seperti Facebook yang mencapai angka 2.28 Juta orang dan untuk media sosial lainnya seperti Youtube mencapai angka lebih dari 1.5 juta, serta untuk Instagram, WeChat dan 
Whatsapp mencapai angka lebih dari 1 juta pengguna. Dengan angka yang besar tersebut, persebaran informasi pun menjadi sangat luas dan cepat.

Persebaran informasi yang sangat cepat tersebut mengakibatkan sulitnya penyaringan kebenaran informasi. Keadaan tersebut mengakibatkan rentannya terjadi disinformasi dan misinformasi dalam penyampaian informasi. Media sosial seperti facebook yang saat ini sekaligus menjadi media informasi memudahkan banyak orang untuk berkomunikasi serta mendapatkan perkembangan informasi tanpa ada penyaringan atau seleksi terhadap informasi yang disebarkan. Tentu permasalahannya adalah pada kredibilitas serta kebenaran suatu informasi untuk dikonsumsi banyak orang. Persebaran fake news memang seringkali terjadi pada media-media seperti ini. Tentu di era posttruth seperti saat ini penyebaran informasi palsu yang didasari pada keresahan mudah sekali untuk dipercaya akibat dorongan perasaan dan egoisme yang lebih tinggi daripada dorongan untuk melihat hal secara objektif. Hal tersebut tentu memudahkan terjadinya disintegrasi dalam masyarakat karena terpancing dengan informasi yang mengadu domba.

Share of adults who believe that take news has a negative effect impact on the internet, politics and political discourse worldwide as of January 2019

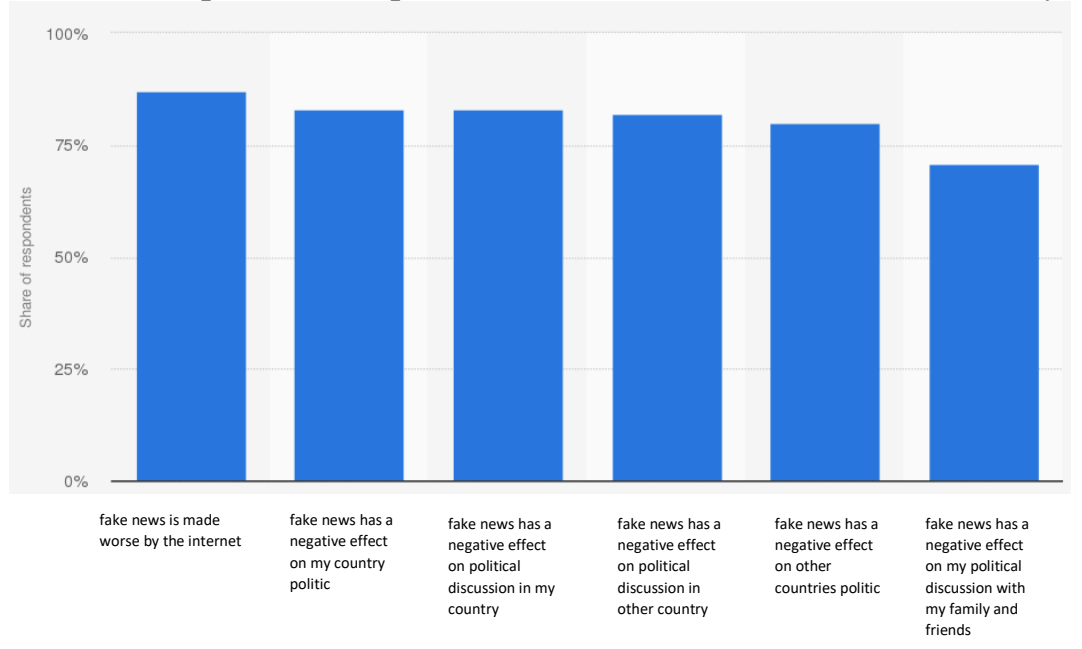

Gambar I: Pengaruh Fake News terhadap masyarakat

Sumber: https://statista.com (2019)

Menurut data yang disampaikan oleh Watson (statista.com, 2019) diatas, fake news menciptakan efek negatif yang besar terhadap kestabilan politik dalam suatu negara. Tidak dapat dipungkiri bahwa persebaran fake news sering dilakukan terhadap informasi yang berhubungan dengan isu sosial dan politik. Hal tersebut dibuktikan dengan penelitian yang dilakukan oleh Mastel pada 2017 yang menunjukkan bahwa hoax yang paling sering diterima oleh masyarakat adalah dalam bidang sosial politik serta masalah SARA (Juditha, 2018). Data tersebut menunjukkan pertumbuhan hoax banyak dilakukan dalam bidang sosial politik sehingga aktor politik menjadi salah satu penyumbang terbesar tersebarnya hoax. Belum lagi saat ini para pemimpin populis banyak yang memiliki perusahaan media sehingga memudahkan mereka untuk mengendalikan siklus informasi pada suatu negara. Indonesia menjadi salah satu negara yang pergulatan politiknya 
sangat kentara terhadap penggunaan media yang masif. Hal tersebut dapat dilihat dari pemilihan Presiden pada 2014 dan 2019 dengan dominasi media-media besar yang sampai memunculkan labelisasi terhadap beberapa media yang dituduh berafiliasi dengan pasangan calon Presiden. Memang penggunaan media dalam meraih dominasi politik menjadi sesuatu yang efektif untuk dilakukan dengan mengajak masyarakat dalam mempercayai sesuatu hal walau tanpa bukti yang nyata (Mclyntre, 2018).

Media pun menjadi sarana gerakan populis dalam menyebarkan informasi untuk memperkokoh integrasi kelompok. Propaganda populis pun dengan mudah dapat disiarkan melalui kemasan-kemasan menarik media, misalnya dalam penyajian berita yang tidak seimbang. Percaturan politik populisme dalam memanfaatkan media hanya akan melahirkan disintegrasi yang menjadi efek residu dari strategi populis. Gerakan populis dalam memanfaatkan media mencoba melakukan personalisasi serta melakukan pendekatan emosional untuk menarik dukungan dari konstituen dan media menjadi salah satu cara untuk mewujudkan hal tersebut secara masif (Mudde, 2007).

Turut terlibatnya perusahaan media nasional maupun transnasional dalam perhelatan politik menjadi sebuah kejanggalan besar dalam proses demokrasi. Padahal Pers dalam beberapa literatur dianggap sebagai lembaga keempat diluar lingkaran trias politica yang mengawasi jalannya pemerintahan secara independen serta objektif (Sahrasad, 2014). Masuknya media pers ke dalam perhelatan politik sekiranya akan menganggu jalannya demokrasi. Tentu apabila pers tidak berada dalam posisi yang benar-benar netral akan mengakibatkan dengan mudahnya produkproduk pers dibajak serta diarahkan untuk kepentingan politik semata. Dengan perilaku yang seperti itu maka produk jurnalistik yang objektif serta transparan akan sulit didapatkan, dengan kata lain masyarakat hanya mengetahui informasi yang "lulus sensor" dari orang-orang yang memiliki kepentingan buruk dalam politik.

Tidak bisa dipungkiri bahwa media menjadi mesin penyubur gerakan populis seperti yang terjadi di berbagai negara termasuk di Indonesia. Kemudahan dalam mengakses informasi tanpa petunjuk kebenaran, tentunya akan menjerumuskan setiap orang yang tidak membacanya secara cermat dan komprehensif. Apalagi fenomena ini banyak terjadi di negara berkembang seperti Indonesia, Philipina, dan India yang tingkat membacanya masih tergolong rendah. Oleh karenanya, media informasi menjadi mesin penggerak utama dalammenyebarpropaganda serta informasi yang tidak objektif untuk mempengaruhi konstituen dalam menentukan dukungan pada gerakan populis.

\section{Populisme dan Kemunduran Demokrasi}

Kebebasan yang diberikan oleh demokrasi tentu tidak selalu digunakan dengan cara positif untuk mengintegrasikan masyarakat. Acap kali, demokrasi disalahgunakan untuk melanggengkan kekuasaan dan/atau memecah belah masyarakat. Banyak praktik menyimpang dalam demokrasi yang saat ini dianggap sebagai hal yang lumrah dan bukan suatu masalah yang berarti,salah satu contohnya adalah gerakan populisme. Kelumrahan demokrasi dapat dirujuk pada perkembangan demokrasi di Amerika Latin pada tahun 1990-an. Hampir tiap pemerintahan pada kala itu telah menggunakan istilah populis yang menjadi gerakan ideal pada saat itu (Grigera, 2017). Hal tersebut ditunjukkan dari adanya gelombang kedatangan populisme yang muncul di Amerika Latin yang terbagi dalam tiga gelombang pada era 1950 sampai 1960-an, gelombang kedua pada 1990-an (pink tide populism), dan gelombang ketiga pada tahun 2000-an (neo populism). 
Tabel 1. Daftar Pemimpin Populis di Amerika Latin

\begin{tabular}{llllll}
\hline & & \multicolumn{2}{c}{ Pemimpin Populis Menurut Gelombang Populisme } \\
Gelombang I & \multicolumn{2}{c}{$\begin{array}{c}\text { Gelombang II } \\
\text { Gelombang III }\end{array}$} \\
Negara & Pemimpin & Negara & Pemimpin & Negara & Pemimpin \\
\hline Argentina & Peron & Argentina & Menem & Argentina & Kirchner \\
Brazil & Vargas & Peru & Fujimori & Brazil & Lula \\
Mexico & Cardenas & Brazil & Collor de Mello & Venezuela & Chavez \\
\hline
\end{tabular}

Gerakan populisme yang muncul di Amerika Latin dilatarbelakangi oleh faktor yang berbeda sesuai dengan gelombang kedatangannya. Pada gelombang pertama disebabkan oleh fenomena politikideologis, gelombang kedua disebabkan oleh faktor ekonomi, dan gelombang ketiga disebabkan oleh politik ekonomi yang timbul dari kekecewaan pada gelombang neo-liberalisme sebelumnya (gelombang kedua). Pemimpin populis pada keitga gelombang tersebut diantaranya cenderung otoriter sehingga jauh dari kata demokratis. Sifat ekslusifitas dari kelompok populis memang tidak dapat dinafikkan akan memunculkan paham otoriter dan kesenjangan dalam pembuatan kebijakan.

Badai populisme dalam sepuluh tahun terakhir kebelakang sedikit banyak telah menciptakan iklim demokrasi yang kurang harmonis. Alih-alih demokrasi yang dimaksudkan Fukuyama (2016) akan membawa kebebasan bagi manusia serta meningkatkan kemartabatan hidup bermasyarakat, malah yang terjadi belakangan ini menggambarkan keadaan sebaliknya. Keadaan demokrasi yang semakin kacau dengan kepemimpinan populis yang diiringi dengan lahirnya banyak kebijakan yang diskriminatif akibat sifat nativisme mengakibatkan kebebasan diartikan hanya sebagai kiasan belaka.

Keterkaitan antara populisme dan kemunduran demokrasi dapat terlihat jelas apabila melihat bagaimana pemimpin populis di Amerika Latin pada gelombang pertama dan kedua menjalankan kekuasaan. Misalnya rezim Juan Peron di Argentina yang melakukan pembungkaman terhadap suara-suara kritis sehingga ia dikenal sebagai pemimpin yang otoriter. Pada masanya hampir tidak ada kebebasan universitas untuk menyampaikan kritikan, menurut Yulio Coltazar (Dalam Imam Modejiono, 1999) pada masa kepemimpinan Peron, para cendikiawan hanya dijadikan sebagai tameng untuk melindungi kekuasaannya sehingga para cendikiawan tersebut diperalat untuk kepentingan negara. Peron merupakan pemimpin populis yang cenderung melakukan pendekatan ekonomi kepada para pemilihnya. Peron memang berusaha untuk sangat dekat dengan industri negara terutama gerakan buruh di Argentina. Namun kedekatan tersebut bukan berarti menjadikan Peron sebagai pemimpin yang demokratis, malah sebaliknya ia lebih dikenal dengan pemimpin yang sangat otoriter.

Di masa modern saat ini, terlihat sangat jelas bagaimana kemunduran demokrasi akibat kepemimpinan para pemimpin populis yang semakin menjamur di berbagai negara demokrasi. Seperti yang telah disampaikan pada pendahuluan diatas bahwa menurut data telah terjadi kemunduran demokrasi dalam sepuluh tahun terakhir. Salah satu faktor yang melatarbelakanginya adalah kebijakan yang cenderung diskriminatif terhadap sekelompok masyarakat. Kebijakan diskriminatif tersebut menurut hemat penulis hanya akan menghasilkan luka minoritas sehingga dari luka tersebut akan melahirkan dendam yang sulit diselesaikan. Kelompok yang diperlakukan secara diskriminatif oleh pemimpin populis seperti di Amerika dan India, bukan berarti tidak dapat bangkit untuk meruntuhkan dominasi para pemimpin mereka. Malah, kelompok tersebut dapat membentuk suatu 
kelompok populis baru yang pada akhirnya akan menyebabkan iklim politik yang chaos dalam penyelenggaraan demokrasi. Represifitas aparat penegak hukum kepada kelompok minoritas hanya akan membuat gerakan ini semakin bertambah besar dan menumbuhkan semangat untuk melengserkan rezim yang tengah berkuasa.

Hal demikian dapat dilihat dalam dinamika politik di Indonesia 6 tahun kebelakang. Kelompok populis sayap kanan sangat gencar untuk mengkritik dan berusaha membangun opini bahwa pemerintah telah gagal dalam menyelenggarakan tugastugasnya. Keberadaan gerakan populis sayap kanan di Indonesia memang tampaknya semakin membesar kurun waktu ke belakang ini akibat isu yang digunakan oleh kelompok populis tersebut merupakan isuisu penindasan dan kebijakan yang tidak pro rakyat, ditambah dengan represifitas aparat yang semakin jelas beberapa waktu kebelakang ini.

Kemunduran demokrasi akibat gerakan populisme bukanlah suatu hal yang mengada-ada. Hal tersebut akibat adanya paham bahwa populisme terdiri dari bagian penghancur prinsip demokrasi, mayoritas rakyat yang ditujukan dengan cara mengelu-elukan sebagian rakyat melalui pemimpinnya menggunakan dukungan massa populis (Urbinati, 2019). Dengan demikian apabila gerakan populis tidak dikendalikan secara baik maka gerakan tersebut hanya berarti sebagai alat untuk menghancurkan demokrasi sekaligus alat balas dendam dari kelompok sakit hati. Cas mudde (2020) pun mengatakan bahwa populisme saat ini mendapatkan stigma negatif sekaligus kontra demokrasi akibat paham anti-imigran serta anti asing (theguardian.com, 2015). Pada titik tersebutlah populisme menjauhkan demokrasi dari esensi aslinya.

Gerakan populis telah menjebak proses demokrasi negara dalam bentuk yang diidealkan oleh mereka. Acap kali, kelompok ini menuntut dengan tuntutan yang sangat eksklusif terhadap kepentingan kelompok mereka seperti apa yang dapat dilihat dari pola gerakan populis di Indonesia. Tuntutan eksklusif mereka juga sering kali tidak memperhatikan kepentingan kelompok lainnya karena menganggap kelompok mereka merupakan kelompok yang terbaik dan seolah memiliki kontribusi besar pada suatu hal. Kelompok ini pun cenderung suka menyalahkan kedudukan kaum minoritas dan kelompok yang tidak disukainya tanpa memberikan solusi terhadap suatu permasalahan (hrw. org, 2020).

Baris argumen panjang diatas menunjukkan keterkaitan antara kejatuhan demokrasi dengan meningkatnya gerakan populisme di dunia. Sejak gelombang pertama populisme di Amerika Latin telah menunjukkan kemunduran demokrasi yang terjadi akibat penguasaan pemimpin yang otoriter seperti Juan Peron. Kerusuhan di beberapa negara demokrasi besar belakangan waktu ini serta fenomena kebijakan yang tidak berimbang (diskriminatif) memberikan legitimasi kemunduran demokrasi modern saat ini.

\section{SIMPULAN}

Demokrasi modern saat ini hadir dengan fenomena populisme yang terjadi sesuai dengan kondisi masyarakat serta geografis suatu negara. Paham populisme memang dibenarkan dalam demokrasi sepanjang tidak berusaha untuk membubarkan suatu negara dan melakukan tindakan pelanggaran hukum lainnya. Malah, populisme merupakan satu fenomena yang merupakan hasil dari dinamika demokrasi liberal saat ini yang memberikan kebebasan terhadap warga negaranya.

Keabsahan populisme dalam demokrasi modern saat ini bukan berarti melegitimasi bahwa populisme selalu membawa dampak positif terhadap demokrasi. Dalam hasil kajian tulisan ini ditemukan bahwa populisme membawa 
banyak dampak terhadap kemunduran demokrasi saat ini. Salah satu hal yang menyebabkan kemunduran tersebut adalah adanya kecenderungan untuk membuat kebijakan yang diskriminatif terhadap warga negara. Kemunduran demokrasi juga sangat terlihat akibat gejolak demokrasi di berbagai negara yang dilandasi pada isu rasial dan nativisme akibat residu dari pemimpin populis. Kelompok populis pun cenderung melepaskan paham kesatuan terhadap heterogenitas masyarakat yang mengakibatkan eksklusifitas kelompok sehingga menghasilkan disintegrasi dalam masyarakat. Pada intinya gerakan populis berperan besar dalam kemunduran demokrasi global akibat ketidakstabilan politik serta lahirnya kebijakan yang diskriminatif.

Sehingga dalam tulisan ini, penulis menyarankan bahwa edukasi politik menjadi hal yang penting untuk menghimbau masyarakat terkait fenomena populisme yang mengakibatkan disintegrasi dalam masyarakat. Selain itu, oleh karena gerakan populis merupakan gerakan yang sah dalam demokrasi maka perlu pengaturan lebih lanjut terkait keamanan politik.

\section{DAFTAR PUSTAKA}

Aart, J.S. (2008). Reconstructing Contemporary Democracy. Indiana Journal of Global Legal Studies: Vol. 15: Iss. 1, Article 13

Albi \& Setiawan J. (2018). Metodologi Penelitian Kualitatif. Bogor: Jejak Publisher

Bonikowski, B. (2016). Three Lessons of Contemporary Populism in Europe and the United States. Fall/Winter, Volume XXIII, Issue I, 9-24

Budiardjo, Miriam. (2003). Dasar-Dasar Ilmu Politik. Jakarta: PT Gramedia Pustaka Utama

Darmawan, A. (2017). Gerakan Populis sebagai Tren Global: Dari Amerika Latin sampai Occupy Movement. Jurnal Insignia Vol 4, No 2, 1-8
Epstein, R.A. (2011). Direct Democracy: Government of the People, by the People, and for the People. Harvard Journal of Law \& Public Policy, Vol. 34, 819-826

Freedom House. (2019). Freedom in The World 2019: Democracy in Retreat. dalam https://freedomhouse.org, diakses pada 11 Juli 2020

Fukuyama, Francis. (2016). The End of History and The Last Man. Yogyakarta: Qalam

Grigera, J. (2017). Populism in Latin America: Old and New Populisms in Argentina and Brazil. International Political Science Review, sage publication, 1-15

Hadiz, V. (2016). Islamic Populism in Indonesia and the Middle East. Cambridge: Cambridge University Press.

Hawkins, Kirk A. (2010). Venezuela's Chavismo and Populism in Comparative Perspective. Cambridge: Cambridge University Press.

Ibrahim, J. (2007). Teori dan Metodologi Penelitian Hukum Normatif. Malang: Penerbit Banyumedia

Inglehart, R.V. \& Norris P. (2016). Trump, Brexit, and the rise of Populism: Economic have-nots and cultural backlash. Faculty Research Working Paper Series No. RWP16-026, Harvard Kenedy School, Cambridge University

Juditha, C. (2018). Interaksi Komunikasi Hoax di Media Sosial serta Antisipasinya. Jurnal Pekommas, Vol. 3 No. 1, 31-44

Kariadi, S. (2009). Jalan Berliku Pintas Populis untuk Kemajuan. Dalam Samadhi, W.P. \& Warouw, N. (Eds.), Demokrasi di Atas Pasir. Yogyakarta: PCD Press

Margiansyah D. (2019). Populisme Di Indonesia Kontemporer: Transformasi Persaingan Populisme Dan 
Konsekuensinya Dalam Dinamika Kontestasi Politik Menjelang Pemilu 2019. Jurnal Penelitian Politik Vol. 16, No. 1, 47-68

Mclyntre, Lee. (2018). Post Truth. US: MIT-Press

Moedjiono, Imam. (1999). Cendikiawan dan Kebebasan Akademik. JPI FIAI Jurusan Tarbiyah Volume V, 67-78

Mudde, C. (2004). The Populist Zeitgeist. Government and Opposition. 39(4), 541-563.

Mudde, C. (2007). Populist Radical Right Parties in Europe. Cambridge: Cambridge University Press.

Mudde, C. (2015). The Problem With Populism. Dipublikasi dalam http:// theguardian.com, diakses pada 12 Juli 2020

Noor, Firman. (2020). Demokrasi di Indonesia dan Arah Perkembangannya di Masa Pandemi. Dalam http://www. politik.lipi.go.id/, diakses pada $12 \mathrm{Juli}$ 2020

Pathak, Priyanka. (2019). Hasil Pemilu India: Partai dengan 'sosok kuat' PM petahana Narendra Modi menang mutlak. Dalam www.bbc.com, diakses pada 12 Juli 2020

Pelfini, Alenjandro. Megatrend Global Populism. dalam Lenger \& Schumpeter (eds). Understanding the Dynamics of Global Inequality. New York: Springer

Repuci, Sarah. (2020). Democracy and pluralism are under assault. Dalam https://freedomhouse.org, diakses pada 14 Juli 2020

Ritonga, Alwi D. \& Adela, Fernanda P. (2020). Mencermati Populisme Prabowo Sebagai Bentuk Gaya Diskursif Saat Kampanye Politik Pada Pemilihan Presiden 2019. Politeia: Jurnal Ilmu Politik, 12 (1), 1-13

Roser, Max, Ritchie and Esteban. (2015). Internet. Dipublikasi di https:// OurWorldInData.org, diakses pada 13 Juli 2020
Kennedi, R. (2020). Dorongan Melawan Tantangan Populis. Dipublikasi dalam https://hrw.org, diakses pada 13 Juli 2020

Sahrasad, H. (2014). Press Democracy and State in Indonesia Post-Soeharto: A Perspective. Jurnal Masyarakat, Kebudayaan dan Politik, Vol. 27 No. 1, 27-43

Schumpeter. (1942). Capitalism, Sosialism, and Democracy. London: George Allen \& Unwin

Toree, C.L.D. (2017). POPULISM REVIVED: Donald Trump and the Latin American Leftist Populists. The Americas, Cambridge Journal University Press, 733-753

Trump, Donald. (2015). Presidential candidacy announcement speech, https://time.com/3923128/donaldtrump-announcement-speech, diakses pada 12 Juli 2020

Ufen, Andreas. (2019). Populisme dan Dampak Ekonomi dan Politiknya yang Ambivalen. Dalam Diana, W. (Ed), Populisme, Politik Identitas dan Erosi Demokrasi di Abad ke 21. Jakarta: Friedrich-Ebert-Stiftung

Urbinati, Nadia. (2019). Political Theory of Populism. Annual Review of Political Science. Vol. 22, 111-127

Watson, A. (2019). Share of adults who believe that fake news has a negative impact on the internet, politics and political discourse worldwide as of January 2019. https://statista.com, diakses pada 14 Juli 2020 